\title{
PSYCHE
}

\begin{tabular}{lll}
\hline Vol. 72 & June, 1965 & No. 2 \\
\hline
\end{tabular}

\section{OBSERVATIONS ON MICROTUS NESTING IN ANT MOUNDS ${ }^{1}$}

\section{By Gerald Scherba \\ California State College at San Bernardino}

A large number of different kinds of organisms inhabit social insect nests and their relationship to their host varies from simple sheltering during winter, through predation, to complex interactions involving specialized secretory glands and other structures. There is a rich literature describing these myrmecophiles and termitophiles and an elaborate terminolo ${ }^{\circ} \mathrm{V}$ defines each of the kinds of relationships between symbiont and host.

The overwhelming majority of these nest inhabitants are arthropods, especially beetles of the family Staphylinidae and allied families. However, vertebrates also inhabit social insect nests. Nichols (I940) reported the synbranch eel Synbranchus marmoratus Block from moist cavities within nests of the leaf-cutting ant Atta sexdens in South America. In Illinois the author has observed wood frogs, Rana sylvatica overwintering in nests of Formica ulkei. Donisthorpe (1927) recorded the slow-worm Anguis fragilis L. within Formica fusca mounds in England; the blind lizard Amphisbaena within Atta nests on the Amazon; the legless lizard Caecilia annulosa within fungus growing ant nests in Guiana; and several species of snakes living with ants in Australia. The Nile Monitor Varanus niloticus (Linn.) incubates its eggs within the termitaria of Nasutitermes in South Africa (Snyder, I929; Cowles, I930). Snakes, lizards, and geckos use termite nests for egg-laying in Jamaica. These animals occupy cavities within the termite nest that were originally excavated by Parakets (Hindwood, I959).

Among the birds, at least 8 species are known to breed in arboreal or terrestrial nests of termites, or in some cases, ants. The list includes 23 species of kingfishers, 13 species of parrots, 4 species of

\footnotetext{
${ }^{1}$ Project 80 of the Jackson Hole Biological Research Station, supported by funds from the National Science Foundation, Grant No. G-23423.

Manuscript received by the editor March 14, 1965.
} 
woodpeckers, 4 species of trogons, 2 species of puffbirds, I species of jacamar and I species of cotinga (Von Hagen, I938; Hindwood, I959; Hardy, 1963). Most of these species hollow out a portion of the nest, and the termites seal the exposed portions so that there is no contact between bird and termite. However, the Rufous Woodpecker, Micropternus brachyurus, which nests in active Crematogaster carton nests, feeds upon the ants which run all about the bird's nest and over the young, without apparent harm.

The Gartered Trogon of central South America nests within wasp nests, but eats the adult wasps before hollowing a nest cavity (Hindwood, r959).

Among the mammals, the aardvark Orycteropus is predatory upon termites and lives within the termitaria (Bequaert, I92 I, and Alfred E. Emerson, personal communication). The dormouse Claviglis has been found nesting with young in a cavity in the side of an arboreal termite nest in the Belgian Congo (Chapin, 1939). The following description adds to the scant record of mammals which inhabit social insect nests.

During observations of a western mound building ant, Formica opaciventris Emery in 1962, the author found the meadow vole, Microtus montanus nanus (Merriam) living within these mounds and both adults and young animals entering and leaving their burrow frequently. This report will describe the burrow system and detail an attempt to define the relationship between vole and ant.

The study area is located in western Wyoming, one mile east of Jackson Lake, near the townsite of Moran, and at an altitude of 2065 meters. The ant nests are located on a mesic silver sagebrush, Artemisia cana, meadow. The soil is a clay loam with an abundant ground cover of herbaceous vegetation.

The nests of Formica opaciventris are earthen mounds with a light covering of thatch. The mounds vary in height to 0.7 meters with basal diameters as large as two meters. The ants are "aggressive," and when disturbed bite readily, exuding droplets of formic acid. There are approximately 400 mounds at the study site and these nests have been under observation since I957 (Scherba, I961, I963, I964).

In the Jackson Hole area Microtus montanus has been captured from these habitats: alpine meadow, subalpine meadow, lush grassforb meadow, wet sedge meadow, willow savannah, timothy meadow, aspen forest, sage-grass community, and willow-alder streamside community. Findley (I95I) and Negus and Findley (1959) state that "this is one of the most versatile mammals . . . from the standpoint of habitat selection." 
While there are no data available on the Microtus population density changes at the study site, casual observation suggests that population levels fluctuate greatly from year to year. The voles are seldom seen during some summers, while they are abundantly evident moving on the ground during other years. 1962 was such a year of apparently high vole density in Jackson Hole.

\section{THE BURROW SYSTEM}

Multiple openings of tunnels are apparent at the base of a large number of the mound nests. Nest 434, a moderately active mound, had eight such openings and this nest was selected for examination (Fig. I).

The tunnel entrances measured 3.0 to $3.8 \mathrm{~cm}$. in diameter. Excavation indicated that two of the tunnels on opposite slopes led downward, then inward, below the soil surface level, then upward, terminating in an oval chamber $12.2 \mathrm{~cm}$. in length and $4.6 \mathrm{~cm}$. high. Other tunnels ended blindly within the mound, joined this chamber after a circuitous path or entered a second, larger, chamber described below. The floor of this first chamber, which was $16.8 \mathrm{~cm}$. below the mound apex, consisted of fine soil and numerous particles of short green and dried plant stems, especially the rush Juncus which grows as a fringe on the mound exterior.

The second chamber, larger and deeper than the one described above, was abundantly lined with soft dried grasses and was accessible by three tunnels which entered it internally from the North, South, and West. These tunnels terminated, eventually, in openings at the ant nest surface. The chamber measured $13.7 \mathrm{~cm}$. in length, $10.7 \mathrm{~cm}$. in heighth, and its floor was located $13.7 \mathrm{~cm}$. below the level of the soil surface and beneath the center of the mound apex. (See Fig. 2). Presumably this chamber serves as the bedding site for Microtus.

Excavation of a second, more active ant mound, nest 460 , revealed seven tunnel entrances with tunnels extending circuitously into the mound for distances of several centimeters. All of these tunnels terminated blindly.

In summary, Microtus activity results in a series of tunnels opening at or just above the level of the soil surface. These tunnels, turning frequently, either end blindly or lead into lined chambers or cavities located within active ant mounds.

\section{POSSIBLE RELATIONSHIPS}

The unexpected presence of a rodent living within active ant nests prompts the inquiry: Are the voles adapted to living within the mounds, either by virtue of being protected from ant bites, or because of avoidance of the voles by the ants? Further, are the ants serving 

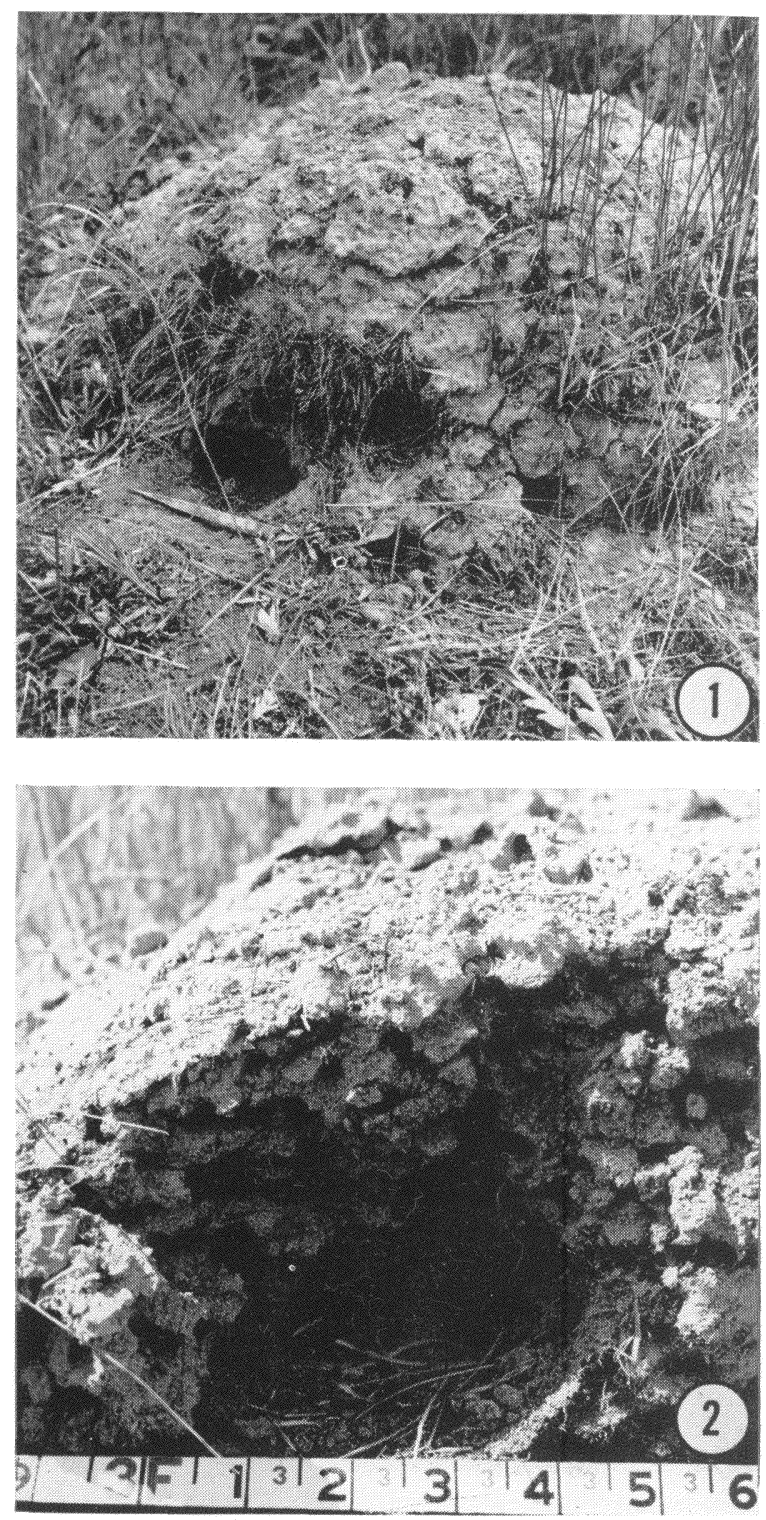

Scherba - Microtus 
as a source of food as well as providing shelter for Microtus?

A Microtus was live trapped and placed in an observation box 60 $\mathrm{cm}$. long by $30 \mathrm{~cm}$. wide by $30 \mathrm{~cm}$. high. A full shovel of nest contents and ants from the same nest as the Microtus was added to the box.

Observations under these circumstances indicate that the worker ants did not avoid Microtus, but instead would attack it whenever the Microtus came into contact with the ants. When contacted by an ant, the Microtus responded by hopping quickly a few centimeters away. Ants which began biting a limb or the tail were usually quickly dislodged by flicking the leg or tail, or by cleaning the leg with the teeth. Some workers were not easily dislodged from the tip of the tail or nares. When bitten in these places, Microtus appeared to be "in distress." On another occasion, a newborn Microtus was seen writhing when attacked by opaciventris.

It, therefore, seems evident that the ants do not avoid Microtus and that Microtus is not insensitive to, or completely protected against, ant bites.

Content analysis of three stomachs examined under a dissecting microscope revealed only freshly chewed bright green plant parts. No recognizable insect fragments were found.

\section{DISCUSSION}

Clearly, Microtus exhibits few of the adaptations one might expect of a rodent which inhabits ant mounds. On this basis, we might speculate, as Professor Negus (personal communication) suggests, that for Microtus montanus ant mounds form a marginal microhabitat utilized only after other, more suitable, sites are already occupied. In a year of apparent high Microtus density, this explanation appears reasonable.

We may categorize the relationship of this vole to the ant as that of a myrmecocole. (Park, I929).

\section{ACKNOWLEDGEMENTS}

Mr. Norman Heryford, Smithsonian Institution, ably assisted this work and his contribution is acknowledged with pleasure. Professor Norman Negus, Tulane University, kindly provided the determination of the species of Microtus under discussion.

Explanation of Plate 7

Figure 1-External openings of Microtus montanus tunnels at the base of Formica opaciventris mounds. A covering of vegetation has been removed. Note forceps for scale.

Figure 2-Cross section of mound showing large central Microtus nest chamber. Dense, soft nesting material of plants has been removed. Note tunnel into chamber at rear. 
The author wishes to express his appreciation to the National Park Service for permission to carry out this investigation within the boundaries of Grand Teton National Park.

BEquAERT, J.

\section{References Cited}

1921. The predacious enemies of ants. Bull. Amer. Mus. Nat. Hist., 45: 271-331.

Chapin, James P.

1939. The birds of the Belgian Congo, pt. II. Bull. Amer. Mus. Nat. Hist., $75: 1-632$.

Collias, Nicholas E.

1964. The evolution of nests and nest-building in birds. Amer. Zool., 4: 175-190.

Cowles, R. B.

1930. The life history of Varanus niloticus (Linn.) as observed in Natal, South Africa. J. Ent. and Zool., 22: 1-31.

1959. Zulu Journal. Field Notes of a Naturalist in South Africa. University of California Press, pp. i-xiv +267.

DONISTHORPe, H. ST. J. K.

1927. The Guests of British Ants. George Routledge and Sons, Ltd., London, pp. xxiii +244.

Findley, James S.

1951. Habitat preferences of four species of Microtus in Jackson Hole, Wyoming. J. Mamm., 32 : 118-120.

HARDY, JOHN WILLIAM

1963. Epigamic and reproductive behavior of the orange-fronted parakeet. Condor, $65: 169-199$.

HAVERSCHMIDT, F.

1960. Some further notes on the nesting of birds in termites' nests. Emu, $60: 53-54$.

Hindwood, K. A.

1959. The nesting of birds in the nests of social insects. Emu, 59: 1-36.

Negus, Norman and James S. Findley

1959. Mammals of Jackson Hole, Wyoming. J. Mamm., 40: 371-381.

Nichols, J. T.

1940. Synbranch eel in ant nest. Copeia, 1940 (3): 202.

PARK, O.

1929. Ecological observations upon the myrmecocoles of Formica ulkei Emery, especially Leptinus testaceus Mueller. Psyche, 36: 195-215.

Scherba, Gerald

1961. Nest structure and reproduction in the mound-building ant Formica opaciventris Emery in Wyoming. J. N. Y. Ent. Soc., 69: 71-87.

1963. Population characteristics among colonies of the ant Formica opaciventris Emery (Hymenoptera: Formicidae). Jour. N. Y. Ent. Soc., $71: 219-232$.

1964. Species replacement as a factor affecting distribution of Formica opaciventris Emery. Jour. N. Y. Ent. Soc., 72: 231-237.

SNYDER, T. E.

1929. Friends and foes of termites or white ants. Zool. Anz., 82: 40-46. Von Hagen, W.

1938. A contribution to the biology of Nasutitermes (sensu stricto). Proc. Zool. Soc. London, $100: 39-49$. 

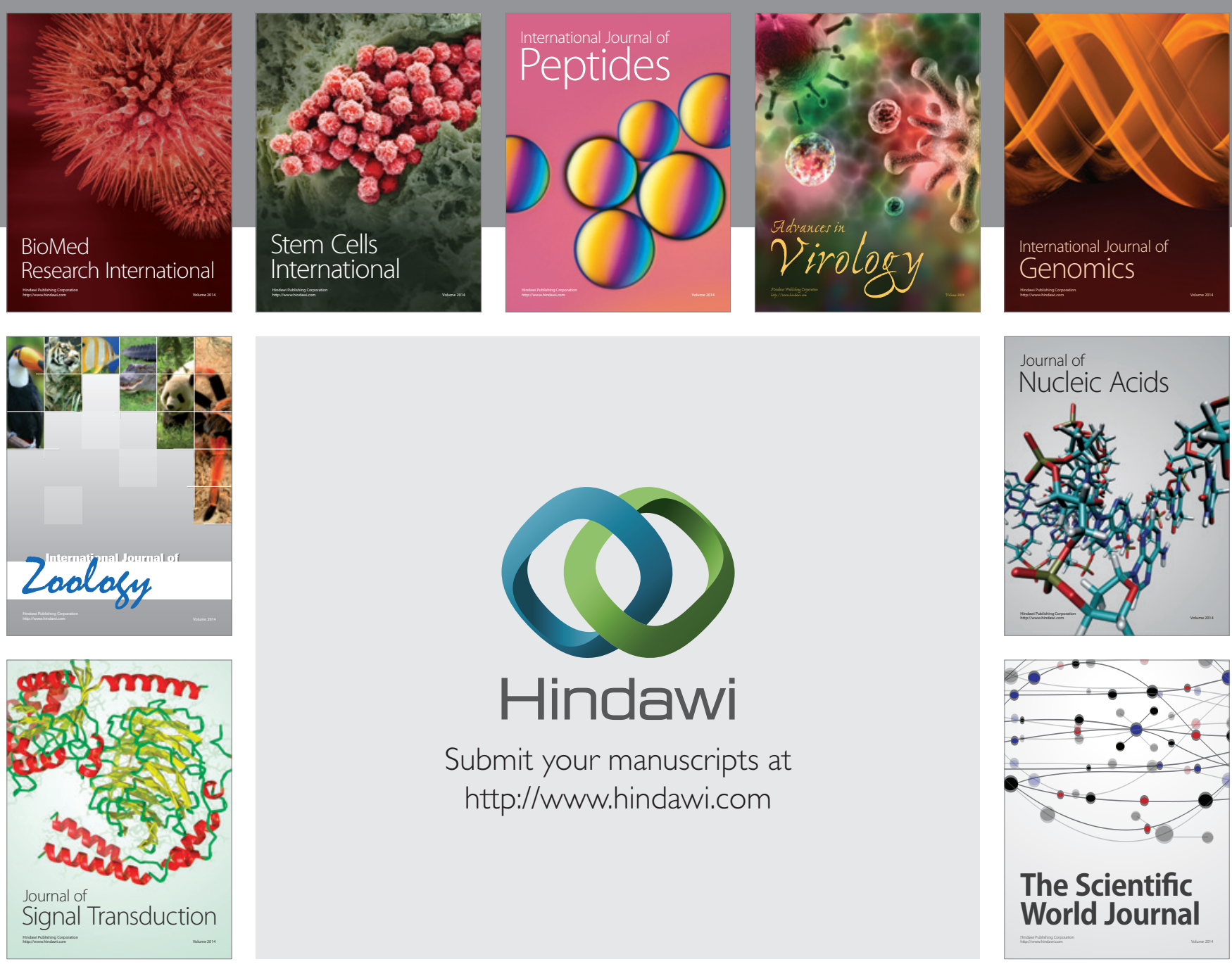

Submit your manuscripts at

http://www.hindawi.com
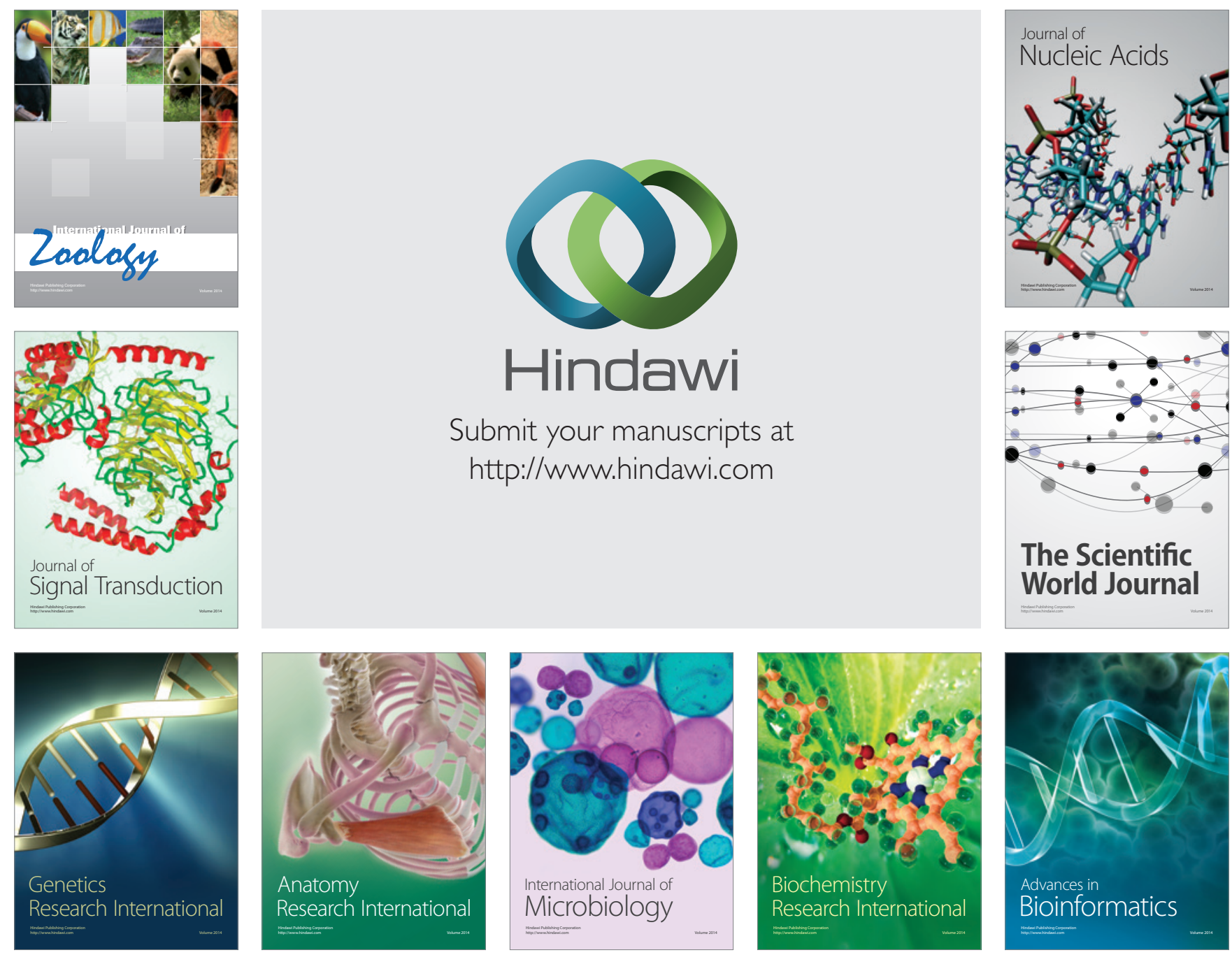

The Scientific World Journal
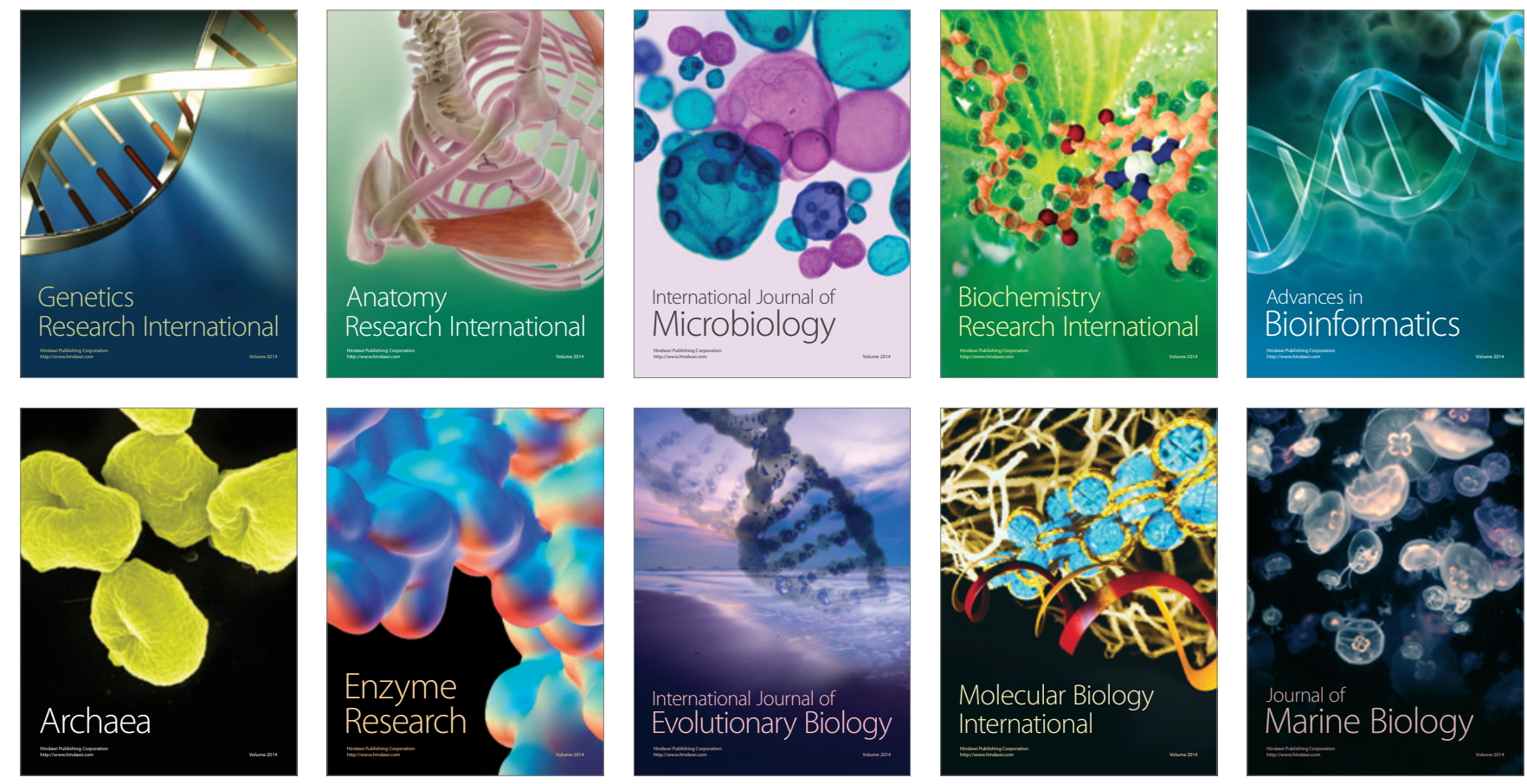